\title{
Pengaruh Model Pembelajaran Penemuan Terbimbing Terhadap Hasil Belajar Matematika Siswa Kelas VII SMP Negeri 3 Raha
}

\author{
(The Influence Of Guided Discovery Learning Model On Mathematics Learning Outcomes \\ Of Students In Class VIII SMP Negeri 3 Raha)
}

\author{
Sitti Amaliyah Adriani ${ }^{1}$, Kadir $^{2}$, Mohammad Salam ${ }^{3}$, Ikman $^{3}$ \\ ${ }^{I}$ Alumnus Jurusan Pendidikan Matematika FKIP Universitas Halu Oleo \\ ${ }^{2}$ Dosen Pendidikan Matematika FKIP dan PPS Universitas Halu Oleo ; Co-author: kadirraea@yahoo.co.id \\ ${ }^{3}$ Dosen Pendidikan Matematika FKIP Universitas Halu Oleo
}

\begin{abstract}
Abstrak: Penelitian ini bertujuan untuk menguji pengaruh model pembelajaran penemuan terbimbing terhadap hasil belajar matematika siswa kelas VII SMP Negeri 3 Raha. Penelitian ini dilaksanakan pada semester genap tahun ajaran 2017/2018. Teknik pengambilan sampel menggunakan teknik purposive sampling. Sampel dalam penelitian ini adalah kelas VII1 sebagai kelas kontrol dan kelas VII3 sebagai kelas eksperimen. Teknik pengumpulan data dilakukan dengan pemberian instrumen berupa lembar observasi dan tes hasil belajar matematika. Teknik analisis data menggunakan statistik deskriptif dan inferensial. Hasil penelitian menunjukkan bahwaterdapat pengaruh yang signifikan model pembelajaran penemuan terbimbing terhadap hasil belajar matematika siswa kelas VII SMP Negeri 3 Raha.Penerapan model pembelajaran penemuan terbimbing lebih baik daripada penerapan model pembelajaran langsung. Hasil belajar matematika siswa dengan model pembelajaran penemuan terbimbing diperoleh rata-rata 71,69; standar deviasi 12,32; dan varians 151,86, dan hasil belajar matematika siswa dengan model pembelajaran langsung diperolehrata-rata 66,12; standar deviasi 10,04; dan varians 100,90.
\end{abstract}

Kata kunci: Model Pembelajaran Penemuan Terbimbing, Hasil Belajar Matematika.

\begin{abstract}
This study aims to examine the effect of guided discovery learning models on mathematics learning outcomes of grade VII students of SMP Negeri 3 Raha. This research was carried out in the even semester of 2017/2018 school year. The sampling technique used purposive sampling technique. The sample in this study is class VII1 as a control class and class VII3 as an experimental class. Data collection techniques are carried out by giving instruments in the form of observation sheets and tests of mathematics learning outcomes. Data analysis techniques use descriptive and inferential statistics. The results showed that there was a significant influence of the guided discovery learning model on the mathematics learning outcomes of grade VII students of SMP Negeri 3 Raha. The application of guided discovery learning models is better than the application of direct learning models. Mathematics learning outcomes of students with guided discovery learning models obtained an average of 71.69; standard deviation 12.32; and variance 151,858 , and mathematics learning outcomes of students with direct learning models obtained on average 66.12; standard deviation of 10.04; and variance 100,897.
\end{abstract}

Keywords: Guided Discovery Learning Model, Mathematics Learning Outcomes.

\section{PENDAHULUAN}

Pendidikan yang dimulai dari pendidikan dasar sampai perguruan tinggi, manusia diajarkan dengan berbagai disiplin ilmu, termasuk matematika. Ilmu matematika sebagai ilmu dasar yang mempunyai peranan penting dalam perkembangan ilmu pengetahuan dan teknologi, misalnya penggunaan logika matematika sebagai dasar bahasa pemrograman, struktur data, sistem digital, teori komputasi, dan rekayasa perangkat lunak. Banyak siswa di sekolah memandang matematika sebagai bidang studi yang paling sulit dipelajari, disebabkan pembelajaran matematika yang cenderung bersifat teacher centered, siswa hanya diajarkan untuk mengerjakan soal, hafalan dan kecepatan berhitung (Fitmawati, 2016: 2-3).

Pembelajaran merupakan suatu proses yang terdiri dari kombinasi dua aspek, yaitu belajar tertuju kepada apa 
yang harus dilakukan oleh siswa, mengajar berorientasi pada apa yang harus dilakukan oleh guru sebagai pemberi pelajaran. Kedua aspek ini akan berkolaborasi secara terpadu menjadi suatu kegiatan pada saat terjadi interaksi antara guru dan siswa, serta siswa dengan siswa disaat pembelajaran sedang berlangsung (Jihad dan Haris, 2013: 11). Pembelajaran adalah upaya dari guru atau dosen untuk siswa/mahasiswa dalam bentuk kegiatan memilih, menetapkan dan mengembangkan metode dan strategi yang optimal untuk mencapai hasil belajar yang diinginkan (Hamzah dan Muhlisrarini, 2014: 58).

Proses pembelajaran matematika dikatakan berhasil apabila siswa mampu memahami dan menguasai konsep matematika yang diajarkan. Empat komponen penting yang berpengaruh bagi keberhasilan belajar matematika siswa, yaitu: bahan belajar, suasana belajar, media dan sumber belajar serta guru sebagai objek pembelajaran. Komponen tersebut sangat penting dalam proses belajar, sehingga melemahnya satu atau lebih komponen dapat mempengaruhi tercapainya tujuan belajar yang optimal.

Pembelajaran matematika adalah serangkaian kegiatan yang melibatkan pendidik dan peserta didik secara aktif untuk memperoleh pengalaman dan pengetahuan matematika (Nurjani, 2015: 3). Pembelajaran matematika merupakan suatu proses belajar mengajar terencana dan terprogram yang melibatkan guru dan siswa dengan segala interaksi di dalamya, dimana guru menyusun suatu rancangan rencana pembelajaran, melaksanakan rancangan pembelajaran, dan mengevaluasi pembelajaran.

Hasil belajar adalah kemampuan yang dimiliki siswa setelah ia menerima pengalaman belajarnya. Hasil belajar mempunyai peranan penting dalam proses pembelajaran. Proses penilaian terhadap hasil belajar dapat memberikan informasi kepada guru tentang kemajuan siswa dalam upaya mencapai tujuan-tujuan belajarnya melalui kegiatan belajar. Hasil belajar dibagi menjadi tiga macam hasil belajar yaitu: (a). Keterampilan dan kebiasaan; (b). Pengetahuan dan pengertian; (c). Sikap dan cita-cita, yang masing-masing golongan dapat di isi dengan bahan yang ada pada kurikulum sekolah (Sukandi, 2014: 23). Sudjana (2013: 36) berpendapat, hasil belajar adalah kemampuan-kemampuan yang dimiliki siswa setelah ia menerima pangalaman belajarnya. Jadi, hasil belajar matematika adalah tingkat keberhasilan dalam menguasai bidang studi matematika setelah memperoleh pengalaman atau proses belajar dalam tes hasil belajar.

Hasil diskusi dan wawancara yang peneliti lakukan pada tanggal 14 Februari 2018 dengan salah seorang guru matematika kelas VII SMP Negeri 3 Raha yaitu ibu Sitti Nurbaya, S.Pd teridentifikasi beberapa kelemahan siswa, antara lain: siswa terlihat kurang antusias, daya kreatifnya rendah, dan siswa bersikap acuh tak acuh dalam kegiatan matematika. Penyebab kelemahan siswa tersebut antara lain: (1) proses pembelajaran masih berpusat pada guru; (2) pola pengajaran selama ini masih dengan tahapan memberikan informasi tentang materi, memberikan contoh dan berikutnya latihan sehinggan pengetahuan siswa bukan hasil konstruksi pemikiran sendiri; (3) Dalam merencanakan penyelesaian soal, siswa tidak diajarkan strategi-strategi yang bervariasi untuk menemukan jawaban soal. Hal tersebut dapat dilihat pada hasil belajar matematika siswa dari data hasil Ulangan Semester Ganjil dimana diperoleh bahwa nilai rata-rata terendah dari lima kelas yaitu 69,20. Rendahnya nilai ulangan semester ganjil matematika siswa, membuktikan bahwa hasil belajar matematika siswa masih rendah.

Keberhasilan belajar siswa tidak terlepas dari peran guru serta kemampuan 
yang ada pada siswa itu sendiri. Unsur penting dalam pembelajaran matematika adalah mendorong siswa serta mengarahkan bagaimana siswa belajar. Rendahnya hasil belajar matematika siswa terjadi karena penerapan model pembelajaran yang kurang tepat yaitu pembelajaran yang masih cenderung berpusat pada guru sehingga siswa kurang aktif dalam proses pembelajaran. Seorang guru dalam menyampaikan materi perlu memilih model pembelajaran mana yang sesuai dengan keadaan kelas atau siswa sehingga siswa merasa tertarik untuk mengikuti pelajaran yang diajarkan.

Oleh karena itu, diperlukan suatu upaya dalam rangka meningkatkan mutu pendidikan dan pengajaran seperti memilih strategi atau cara dalam menyampaikan materi pelajaran agar diperoleh peningkatan hasil belajar metematika siswa. Misalnya guru membimbing siswa untuk bersama-sama terlibat aktif dalam proses pembelajaran dan mampu membantu siswa berkembang sesuai dengan taraf intelektualnya sehingga lebih menguatkan pemahaman siswa terhadap konsep-konsep yang diajarkan, serta dilakukan upaya perbaikan dari segi materi, proses pembelajaran, perbaikan dan dukungan sarana dan prasarana, pembagian materi menjadi bagian-bagian yang lebih sederhana atau peningkatan mutu siswa di sekolah.

Perlu digunakan sebuah model pembelajaran yang dapat menempatkan siswa sebagai subjek (pelaku) pembelajaran dan guru hanya bertindak sebagai fasilitator dalam proses pembelajaran tersebut. Salah satunya dengan menerapkan model pembelajaran penemuan terbimbing. Model pembelajaran penemuan terbimbing merupakan salah satu model pembelajaran dimana guru tidak langsung memberikan hasil akhir atau kesimpulan dari materi yang disampaikannya melainkan siswa diberi kesempatan mencari dan menemukan hasil data tersebut. Jadi, proses pembelajaran ini yang akan diingat oleh siswa sepanjang masa, dan hasil yang ia dapat tidak mudah dilupakan sehingga dengan model pembelajaran penemuan terbimbing diharapkan dapat meningkatkan hasil belajar matematika siswa.

Pembelajaran penemuan terbimbing adalah suatu rangkaian kegiatan pembelajaran yang melibatkan secara maksimal seluruh kemampuan peserta didik untuk mencari dan menyelidiki secara sistematis, kritis, dan logis,sehingga mereka dapat menemukan sendiri pengetahuan, sikap dan keterampilan sebagai wujud adanya perubahan perilaku (Suhana, 2014: 44). Pembelajaran penemuan terbimbing merupakan model pembelajaran yang melibatkan siswa belajar secara aktif dan mandiri dalam menemukan suatu konsep atau teori, pemahaman, dan pemecahan masalah. Prosespenemuan tersebut membutuhkan guru sebagai fasilitator dan pembimbing, sehingga model pembelajaran sesuai prosedur sistematis dalam mengorganisasikan pengalaman belajar untuk mencapai tujuan belajar.

Pembelajaran dengan menggunakan model pembelajaran penemuan terbimbing bertujuan untuk memperbaiki pola pengajaran yang selama ini hanya mengarah kepada menghafal fakta-fakta saja, tetapi tidak memberikan kepada siswa pengertian konsep-konsep dan atau prinsip-prinsip yang terdapat dalam suatu materipelajaran. Priansa (2015: 219) menegaskan bahwa, pembelajaran penemuan terbimbing merupakan model pembelajaran yang menciptakan situasi belajar yang melibatkan siswa belajar secara aktif dan mandiri dalam menemukan suatu konsep atau teori, pemahaman, dan pemecahan masalah. Proses penemuan tersebut membutuhkan guru sebagai fasilitator dan pembimbing. Banyaknya bantuan yang diberikan guru tidak mempengaruhi peserta didik untuk melakukan penemuan sendiri. 
Syah (2004: 244) mengemukakan tahap-tahap dalam implementasi pembelajaran penemuan terbimbing adalah sebagai berikut:

\section{Stimulation}

Pada tahap ini peserta didik dihadapkan pada sesuatu yang menimbulkan kebingungannya, kemudian dilanjutkan untuk tidak memberi generanisasi, agar timbul keinginan untuk menyelidiki sendiri. Pada tahap ini guru dapat memulai kegiatan proses belajar mengajar dengan mengajukan beberapa pertanyaan, anjuran membaca buku, dan aktivitas belajar lainnya yang mengarah pada persiapan pemecahan masalah. Stimulasi pada tahap ini berfungsi untuk menyediakan kondisi interaksi belajar yang dapat mengembangkan dan membantu peserta didik dalam mengeksplorasi bahan.

\section{Problem Statement}

Pada tahap ini guru memberi kesempatan kepada peserta didik untuk mengidentifikasi sebanyak mungkin agenda-agenda masalah yang relevan dengan bahan pelajaran, kemudian salah satunya dipilih dan dirumuskan dalam bentuk hipotesis (jawaban sementara atas pertanyaan masalah).

\section{METODE PENELITIAN}

Penelitian ini dilaksanakan pada semester genap tahun ajaran 2017/2018 pada siswa kelas VII SMP Negeri 3 Raha yang dimulai pada tanggal 2 Mei 2018 sampai pada tanggal 19 mei 2018. Populasi dalam penelitian ini adalah seluruh siswa kelas VII SMP Negeri 3 Raha tahun pelajaran 2017/2018 yang tersebar pada lima kelas paralel, yaitu kelas $\mathrm{VII}_{1}$ sampai dengan kelas $\mathrm{VII}_{5}$. Berdasakan hasil wawancara dengan guru matematika di sekolah, diperoleh informasi bahwa siswa kelas VII SMP Negeri 3 Raha terdiri dari lima kelas tanpa ada kelas unggulan, yang tersebar secara

\section{Data Collection}

Pada tahap ini guru memberikan kesempatan peserta didik untuk mengumpulkan informasi sebanyakbanyaknya yang relevan untuk membuktikan benar atau tidaknya hipotesis.

4. Data Processing

Pada tahap ini siswa mengolah data yang sudah didapat di identifikasi atau dianalisis untuk membentuk suatu konsep atau generalisasi. Dari generalisasi tersebut peserta didik akan mendapatkan pengetahuan baru tentang alternatif jawaban/penyelesaian yang perlu mendapat pembuktian secara logis.

5. Verification

Pada tahap ini peserta didik melakukan pemeriksaan secara cermat untuk membuktikan kebenaran atau setidaknya hipotesis yang ditetapkan tadi dengan temuan alternatif, dihubungkan dengan hasil data processing.

\section{Generalization}

Pada tahap ini siswa menarik kesimpulan atau membuat kesimpulan atas jawaban dari permasalahan yang telah di berikan sebelumnya.

heterogen, dalam arti bahwa secara umum dalam masing-masing kelas terdapat siswa yang berkemampuan tinggi, sedang, dan rendah.

Pengambilan sampel pada penelitian ini dilakukan secara purposive sampling, dengan mengambil dua kelas berbeda yang mempunyai nilai rata-rata terendah yang relatif sama. Sampel pada penelitian ini yaitu kelas VII $_{1}$ sebagai kelas kontrol dan kelas $\mathrm{VII}_{3}$ sebagai kelas eksperimen. Penentuan kelas ini dilakukan secara random.

Penelitian ini menggunakan desain penelitian Posttest Only Control Group 
Design. Desain ini dapat dilihat pada tabel 1.

Tabel 1. Desain penelitian Posttest Only Control Group Design

\begin{tabular}{lcc}
\hline Kelompok & Perlakuan & Posttest \\
\hline Eksperimen & $\mathrm{X}_{1}$ & $\mathrm{Y}_{1}$ \\
Kontrol & $\mathrm{X}_{2}$ & $\mathrm{Y}_{2}$ \\
\hline
\end{tabular}

Suryabrata dalam Suparno (2012: 36).

Keterangan:

$X_{1}=$ Pembelajaran matematika dengan model pembelajaran penemuan terbimbing.

$X_{2}=$ Pembelajaran matematika dengan model pembelajaran langsung.

$Y_{1}=$ Hasil posttest siswa pada kelas eksperimen.

$Y_{2}=$ Hasil posttest siswa pada kelas kontrol.

Instrumen yang digunakan dalam penelitian ini, yaitu lembar observasi dan tes hasil belajar matematika.

Perhitungan validitas setiap butir soal hasil uji coba instrumen tes hasil belajar matematikadi hitung dengan menggunakan rumus korelasi product moment, yaitu (Lestari dan Yudhanegara, 2017:193):

$$
\mathrm{r}_{\mathrm{xy}}=\frac{N \sum x y-\left(\sum x\right)\left(\sum y\right)}{\sqrt{\left\{N \sum x^{2}-\left(\sum x\right)^{2}\right\}\left\{N \sum y^{2}-\left(\sum y^{2}\right)\right\}}}
$$

Keterangan:

$r_{x y}=$ koefisien korelasi antara skor butir soal dengan skor total

$\mathrm{N}=$ Jumlah subyek

$\mathrm{x}=$ Jumlah skor item

$\mathrm{y}=$ jumlah skor total

Validitas butir soal ditentukan oleh nilai $r_{x y}$, pengujian dilakukan pada $\alpha=$ 0,05 dengan kriteria pengujian, jika $r_{x y}>$ $\mathrm{r}_{\text {tabel }}$ maka butir soal tersebut valid dan jika $r_{x y}<r_{\text {tabel }}$ maka butir soal tidak valid.

Hasil $r$ yang diperoleh dari perhitungan dibandingkan pada tabel kritis $\mathrm{r}$ product moment dengan signifikansi $5 \%$ dan $\mathrm{N}$ sesuai dengan jumlah responden uji coba tes yaitu 15 orang siswa. Berdasarkan perhitungan dengan rumus korelasi product moment, maka diperoleh soal yang valid adalah soal nomor 1, 4, 5, 6, dan 7. Adapun yang tidak valid adalah soal nomor 2 , dan 3 .
Uji reliabilitas tes menggunakan rumus Alpha Cronbach yaitu:

$$
r_{11}=\frac{n}{n-1}\left(1-\frac{\sum \sigma_{i}^{2}}{\sigma_{t}^{2}}\right)
$$

Keterangan:

$r_{11}=$ Koefisien reliabilitas

$n=$ Banyak butir total yang valid

$\sigma_{i}^{2}=$ Varians skor butir

$\sigma_{t}^{2}=$ Varians skor total.

Pemberian derajat terhadap koefisien reliabilitas tes pada umumnya digunakan patokan menurut Arikunto (2015: 235) sebagai berikut:

$0 \leq r_{11} \leq 0,20$ reliabilitas : sangat rendah

$0,20<r_{11} \leq 0,40$ reliabilitas : rendah

$0,40<r_{11} \leq 0,60$ reliabilitas : sedang

$0,60<r_{11} \leq 0,80$ reliabilitas : tinggi

$0,80<r_{11} \leq 1,00$ reliabilitas : sangat tinggi

Hasil analisis reliabilitas posttest hasil belajar matematika dengan menggunakan alat bantu SPSS diperoleh koefisien reliabilitasnya sebesar 0.972 yang dapat diinterpretasikan dalam kategori sangat tinggi. Selain itu, koefisien reliabilitas $=0.972>0.65$, maka reliabilitas perangkat tes ini dianggap sangat memuaskan.

Data hasil belajar dalam penelitian ini dianalisis dengan menggunakan dua jenis statistik, yaitu analisis deskriptif dan analisis inferensial. Analisis deskriptif dimaksudkan untuk mendeskripsikan hasil belajar matematika siswa melalui nilai rata-rata $(\bar{x})$, median $(\mathrm{Me})$, modus $(\mathrm{Mo})$, 
varians $\left(\mathrm{S}^{2}\right)$, standar deviasi $(\mathrm{S})$, nilai maksimum $\left(\mathrm{X}_{\max }\right)$, dan nilai minimum $\left(\mathrm{X}_{\min }\right)$. Penyajian hasil analisis desktiptif dapat dilengkapi dengan tabel, grafik dan diagram yang diperoleh dengan bantuan SPSS. Sedangkan Analisis inferensial dimaksudkan untuk menguji hipotesis, namun terlebih dahulu melalui tahapan uji prasyarat, yaitu uji normalitas data dan uji homogenitas.

Uji normalitas data dimaksudkan untuk mengetahui apakah data yang diperoleh berasal dari populasi yang berdistribusi normal atau tidak. Karena jumlah sampel masing masing, 23 untuk kelas eksperimen dan 24 untuk kelas kontrol, yang artinya < 50. Maka uji normalitas data kelas eksperimen dan kelas kontrol yang digunakan adalah uji Shapiro-Wilk.

berikut:

Hipotesis statistiknya sebagai

$\mathrm{H}_{0}$ : sampel berasal dari populasi yang berdistribusi normal

$\mathrm{H}_{1}$ : sampel berasal dari populasi yang berdistribusi tidak normal.

Rumus manual uji Shapiro-Wilk adalah

$T_{\text {hitung }}=\frac{1}{D}\left[\sum_{i=1}^{k} a_{i}\left(X_{n-i+1}-X_{i}\right)\right]^{2}$

dimana,

$$
D=\sum_{i=1}^{n}\left(X_{1}-\bar{X}\right)^{2}
$$

(Razali dan Wah, 2011: 21-33)

Keterangan:

$\mathrm{a}_{\mathrm{i}}=$ Koefisien uji Shapiro Wilk

$\mathrm{X}_{\mathrm{n}-\mathrm{i}+1}=$ Angka ke $\mathrm{n}-\mathrm{i}+1$ pada data

$\mathrm{X}_{\mathrm{i}}=$ Angka ke i pada data

$\bar{X}=$ Rata-rata data.

Kriteria pengambilan keputusan secara manual yaitu signifikansi dibandingkan dengan tabel Shapiro Wilk. Signifikansi uji nilai $\mathrm{T}_{\text {hitung }}$ dibandingkan dengan nilai tabel Shapiro-Wilk untuk dilihat posisi probabilitasnya (p). Jika nilai $\mathrm{p} \geq 5 \%$ maka $\mathrm{H}_{0}$ diterima, sebaliknya jika nilai $\mathrm{p}<5 \%$ maka $\mathrm{H}_{0}$ ditolak.
Uji homogenitas digunakan untuk memperlihatkan bahwa dua atau lebih kelompok data sampel berasal dari populasi yang memiliki varians yang sama.

Perumusan hipotesis:

$\mathrm{H}_{0}$ : varians dari dua atau lebih kelompok populasi data adalah homogen

$\mathrm{H}_{1}$ : varians dari dua atau lebih kelompok populasi adalah tidak homogen

Secara manual uji homogenitas dengan menggunakan uji $\mathrm{F}$ digunakan rumus sebagai berikut

$$
\mathrm{F}_{\text {hitung }}=\frac{\text { varians terbesar }}{\text { varians terkecil }}
$$

Kriteria pengambilan keputusannya dengan Uji Fisher yaitu jika $F_{\text {hitung }} \leq F_{\text {tabel }}$ , maka $\mathrm{H}_{0}$ diterima (kedua varians homogen). Sebaliknya, jika $F_{\text {hitung }}>F_{\text {tabel }}$, maka $\mathrm{H}_{0}$ ditolak (kedua varians tidak homogen).

Pengujian hipotesis dengan uji-t, untuk mengetahui apakah hasil belajar matematika siswa yang diajar model pembelajaran penemuan terbimbinglebih baik dari pada hasil belajar matematika siswa yang diajar dengan model pembelajaran langsung.

Jika ditemukan data terdistribusi normal dan varians homogen, maka pengujian hipotesis yang digunakan adalah statistik uji-t. Rumus t-test sebagai berikut

$$
\mathrm{t}_{\text {hitung }}=\frac{\overline{X_{1}}-\bar{X}_{2}}{\mathrm{~S}_{\mathrm{g}} \sqrt{\frac{1}{n_{1}}+\frac{1}{n_{2}}}}
$$

dengan,

$$
\mathrm{S}_{\mathrm{g}}=\sqrt{\frac{\left(\mathrm{n}_{1}-1\right) \mathrm{S}_{1}^{2}+\left(\mathrm{n}_{2}-1\right) \mathrm{S}_{2}^{2}}{\mathrm{n}_{1}+\mathrm{n}_{2}-2}}
$$

Keterangan:

$\mathrm{t}=$ angka atau koefisien derajat perbedaan mean kedua kelompok.

$\bar{X}_{1}=$ rata-rata hasil belajar kelas eksperimen

$\bar{X}_{2}=$ rata-rata hasil belajar kelas kontrol 
$n_{1}=$ jumlah siswa kelas eksperimen

$n_{2}=$ jumlah siswa kelas kontrol

$S_{\text {gab }}=$ varians gabungan.

$\mathrm{S}_{1}^{2}=$ varians data sampel kelas eksperimen

$\mathrm{S}_{2}^{2}=$ varians data sampel kelas kontrol

Perumusan hipotesis:

Keterangan:

$$
\begin{aligned}
& \mathrm{H}_{0}: \mu_{1} \leq \mu_{2} \\
& \mathrm{H}_{1}: \mu_{1}>\mu_{2}
\end{aligned}
$$

$\mu_{1}$ : rata-rata hasil belajar matematika siswa yang diajar dengan model pembelajaran penemuan terbimbing.

\section{HASIL PENELITIAN}

Data aktivitas guru pada setiap pertemuan pada saat pembelajaran dengan menggunakan model pembelajaran penemuan terbimbing pada materi $\mu_{2}$ : rata-rata hasil belajar matematika siswa yang diajar dengan model pembelajaran langsung.

Kriteria pengambilan keputusan yakni jika $\mathrm{t}_{\text {hitung }} \leq \mathrm{t}_{\text {tabel }}(\alpha=0.05$; db) maka $\mathrm{H}_{0}$ diterima. Sebaliknya jika $\mathrm{t}_{\text {hitung }}>$ $\mathrm{t}_{\text {tabel }}(\alpha=0.05 ; \mathrm{db})$ maka $\mathrm{H}_{0}$ ditolak.

Pengolahan data dalam penelitian dibantu dengan program aplikasi statistik SPSS.

Tabel 2. Hasil Observasi Aktivitas Guru

\begin{tabular}{ccc}
\hline Pertemuan & Skor Total & Persentase (\%) \\
\hline 1 & 12 & 75 \\
2 & 14 & 87.5 \\
3 & 14 & 87.5 \\
4 & 15 & 93.75 \\
\hline
\end{tabular}

Berdasarkan Tabel 2, persentase keberhasilan pengelolaan pembelajaran pada pertemuan pertama mencapai $75 \%$. Pertemuan kedua mencapai $87.5 \%$ dikarenakan guru dan siswa telah mengadakan refleksi terhadap pertemuan pertama. Pada pertemuan ketiga masih tetap pada $87.5 \%$ dikarena siswa dihadapkan dengan persoalan baru pada materi penyajian data. Pada pertemuan ke empat peneliti sudah mampu menutupi penyajian data, terdiri dari empat pertemuan, tersajikan dalam Tabel 2 berikut.

Tabel 3. Hasil Observasi Aktivitas Siswa

\begin{tabular}{ccc}
\hline Pertemuan & Skor Total & Persentase (\%) \\
\hline 1 & 9 & 75 \\
2 & 11 & 91.67 \\
3 & 10 & 83.33 \\
4 & 12 & 100 \\
\hline
\end{tabular}

Berdasarkan Tabel 3, persentase keaktifan siswa pada pertemuan pertama mencapai $75 \%$. Pada pertemuan tersebut, kesalahan-kesalahan pada pertemuan sebelumnya sehingga persentase pengeloaan kelas memiliki peningkatan yaitu $90 \%$ artinya tahapan pelaksanaan pembelajaran yang telah direncanakan dapat dilaksanakan dengan baik.

Data aktivitas siswa yang ada pada setiap pembelajaran menggunakan model pembelajaran penemuan terbimbing, terdiri dari empat pertemuan, tersaji dalam Tabel 3 berikut. 
dihadapkan dengan model belajar secara diskusi, sehingga kerjasama antar siswa dalam kelompok menjadi tidak maksimal. Persentase keaktifan siswa pada pertemuan kedua mencapai 91.67\%. Pada pertemuan kedua ini, siswa sudah tidak malu-malu lagi untuk bekerjasama dengan teman kelompoknya sehingga siswa terlihat antusias mengikuti pembelajaran. Keberhasilan ini disebabkan oleh siswa yang sudah mau bekerjasama dengan anggota kelompok dan mau berbagi dengan anggota kelompok lain.

Hasil analisis deskriptif data hasil belajar matematika siswa kelas eksperimen dan kelas kontrol menggunakan bantuan aplikasi IBM SPSS Statistics, dapat dilihat pada Tabel 4.

Tabel 4. Deskripsi Hasil Belajar Matematika SiswaKelas Eksperimen dan kelas

Kontrol

\begin{tabular}{ccc}
\hline \multicolumn{3}{c}{ Statistics } \\
\hline & Kelas Eksperimen & Kelas Kontrol \\
\hline Minimum & 55 & 50 \\
Maximum & 95 & 88 \\
Mean & 71.695 & 66,125 \\
Median & 70 & 64 \\
Modus & 70 & 60 \\
Std. Deviation & 12.323 & 10.044 \\
Variance & 151.858 & 100.897 \\
Skewness & 0.383 & 0.435 \\
\hline
\end{tabular}

Berdasarkan data Tabel 4 tentang analisis deskriptif hasil belajar matematika siswa pada kelas eksperimen dan kelas kontrol secara kasat mata terlihat bahwa hasil belajar matematika siswa di kelas eksperimen lebih baik, namun perbedaan hasil belajar kedua kelas tidak terlalu mencolok.
Pada analisis inferensial, terdapat beberapa tahap analisis yang menjadi prasyarat untuk melakukan analisis uji hipotesis yaitu uji normalitas data dan uji homogenitas data. homogenitas maka dilanjutkan dengan uji hipotesis.

Hasil perhitungan uji normalitas data dengan SPSS dapat dilihat pada Tabel 5

Tabel 5. Hasil Analisis Uji Normalitas Data Posttest Tests of Normality

\begin{tabular}{ccccc}
\multicolumn{5}{c}{ Tests of Normality } \\
\cline { 3 - 5 } & \multirow{2}{*}{ Kelas } & \multicolumn{3}{c}{ Shapiro-Wilk } \\
\cline { 3 - 5 } & Statistic & Df & Sig. \\
\hline \multirow{2}{*}{ HBM } & Kelas_Eksperimen & .926 & 23 & .091 \\
& Kelas_Kontrol & .952 & 23 & .325 \\
\hline
\end{tabular}

Berdasarkan hasil uji normalitas di atas, diperoleh nilai sig. untuk kelas eksperimen $=0.091>0.05=\alpha$ maka $\mathrm{H}_{0}$ diterima. Hal ini berarti bahwa data hasil belajar matematika siswa pada kelas eksperimen berdistribusi normal. Pada kelas kontrol diperoleh nilai sig. $=0.325>$ $0.05=\alpha$ maka $\mathrm{H}_{0}$ diterima. Hal ini berarti bahwa data hasil belajar matematika siswa pada kelas kontrol berdistribusi normal.

Hasil uji homogenitas varians data dari kedua kelompok sampel dengan bantuan SPSS dapat dilihat pada Tabel 6 
Tabel 6. Hasil Analisis Uji Homogenitas Varians Data Posttest

\begin{tabular}{cccc}
\hline Levene Statistic & df1 & df2 & Sig. \\
\hline 1.090 & 1 & 45 & .302 \\
\hline
\end{tabular}

Berdasarkan hasil uji homogenitas varians diperolehnilai $\mathrm{Sig}=0.302$, karena nilai $\mathrm{Sig}=0.302>0.05=\alpha$ maka $\mathrm{H}_{0}$ diterima. Hal ini berarti bahwa data yang diperoleh memiliki varians yang homogen.
Pengujian hipotesis dengan uji-t, untuk data sampel saling bebas (Independent Sample t-test) dilakukan dengan menggunakan SPSS. Adapun hasil analisis uji hipotesis dapat dilihat pada Tabel 7

Tabel 7. Hasil Analisis Uji Hipotesis

\section{Levene's Test for}

Equality of Variance

\begin{tabular}{cccccc} 
& F & Sig. & t & df & Sig.(2-tailed) \\
\hline NILAI Equal variances & 1.090 & 0.302 & 1.702 & 45 & 0.096 \\
$\begin{array}{l}\text { assumed } \\
\begin{array}{l}\text { Equal variances } \\
\text { not assumed }\end{array}\end{array}$ & & 1.695 & 42.467 & 0.097 \\
\hline
\end{tabular}

Berdasarkan hasil analisis uji-t diperoleh $t_{\text {hitung }}>t_{\text {tabel }}(\alpha=0.05 ; \mathrm{db}=45)=$ $1.702>1.679$ atau nilai $\frac{\text { sig.(2-tailed })}{2}=$ $\frac{0,096}{2}=0.048<0.05$. Jadi, $\mathrm{H}_{0}$ ditolak atau dapat dikatakan bahwa terdapat pengaruh yang signifikan penggunaan model

\section{PEMBAHASAN}

Waktu pembelajaran dalam
pelaksanaan penelitian antara kelas
eksperimen dan kelas kontrol adalah sama,
masing-masing 10 jam pelajaran. Kedua
kelas diberikan waktu 80 menit pada
pertemuan kelima yang digunakan untuk
pelaksanaan Posttest hasil belajar
matematika siswa.

Kedua kelas diberikan materi yang sama yaitu materi pokok penyajian data. Perbedaan yang diberikan kepada kelas eksperimen dan kelas kontrol yaitu pada bahan ajar, LKS dan perlakuan dimana guru matematika di sekolah itu yang mengajar di kelas kontrol dengan menggunakan pembelajaran langsung, sedangkan kelas eksperimen peneliti yang memberi perlakuan langsung dengan pembelajaran penemuan terbimbing daripada pengaruh model pembelajaran langsung terhadap hasil belajar matematika siswa kelas VII SMPN 3 Raha. menggunakan model pembelajaran penemuan terbimbing.

Selama empat kali pertemuan pembelajaran, diperoleh data aktivitas guru dan siswa dalam mengelolah dan mengikuti jalannya proses pembelajaran yang dilaksanakan pada kelas eksperimen dengan penerapan model pembelajaran penemuan terbimbing. Keberhasilan pengelolaan pembelajaran oleh guru selama pembelajaran dengan model pembelajaran penemuan terbimbing berkategori sangat baik.

Guru membahas pokok-pokok materi hari itu, yaitu penyajian data. Pada kegiatan pendahuluan guru diawali dengan mengajak siswa untuk berdoa sebelum memulai pembelajaran dan mengungkap materi prasyarat. Setelah itu, proses 
pembelajaran dilanjutkan dengan mengelompokkan siswa-siswa menjadi lima (5) kelompok yang terdiri dari empat (4) dan lima (5) siswa yang memiliki kemampuan yang heterogen. Respon siswa terhadap penerapan model pembelajaran penemuan terbimbing pada pertemuan pertama tersebut dapat dikatakan kurang baik, sebab mayoritas siswa tidak setuju untuk belajar dengan metode diskusi kelompok, sehingga siswa-siswa yang tidak setuju tersebut tidak kooperatif. Demi kelancaran pembelajaran, guru memilih untuk menjelaskan sekilas tentang bagaimana pelaksanaan model pembelajaran penemuan terbimbing dalam pembelajaran dan dampaknya terhadap kemampuan berpikir kreatif siswa. Oleh sebab itu, merekapun menerima dan setuju melanjutkan pembelajaran.

Berdasarkan hasil observasi aktivitas guru dan siswa, dapat dikatakan bahwa pencapaian keterlaksanaan pembelajaran tergolong berhasil karena presentase pencapaian keterlaksanaan pembelajaran bisa mencapai $80 \%$. Setelah proses pembelajaran selesai, pada pertemuan terakhir diadakan posttest. Kemudian, data hasil posttest tersebut diolah menggunakan SPSS. Berdasarkan hasil analisis deskriptif dari data yang diperoleh melalui posttest hasil belajar matematika siswa yang diujikan pada kelas eksperimen dan kelas

\section{KESIMPULAN DAN SARAN}

Berdasarkan hasil penelitian dan pembahasan dalam penelitian ini, maka dapat dikemukakan beberapa kesimpulan sebagai berikut.

1. Proses pembelajaran dengan menggunakan model pembelajaran Penemuan Terbimbing pada kelas VII SMP Negeri 3 Raha berkategori sangat baik.

2. Terdapat pengaruh yang signifikan model pembelajaran Penemuan Terbimbing terhadap hasil belajar matematika siswa kelas VII SMP kontrol menunjukkan bahwa rata-rata hasil belajar matematika pada kelas eksperimen lebih baik dari pada kelas kontrol

Berdasarkan analisis inferensial ditemukan bahwa terdapat pengaruh yang signifikan penerapan model pembelajaran penemuan terbimbing terhadap hasil belajar matematika siswa. Adanya pengaruh hasil belajar ini terjadi karena pembelajaran dengan menggunakan model pembelajaran terbimbing. Salah satu teori pembelajaran yang mendukung adanya model pembelajaran penemuan terbimbing adalah teori Bruner. Dalam teorinya, Bruner menyatakan bahwa model pembelajaran penemuan terbimbing merupakan kegiatan pembelajaran yang melibatkan secara maksimal seluruh kemampuan siswa untuk mencari dan menemukan sesuatu (benda,manusia, atau menemukan sesuatu peristiwa) secara sistematis, kritis, logis, analitis sehingga mereka dapat merumuskan sendiri penemuannya dengan penuh percaya diri.Pembelajaran penemuan memiliki kelebihan yaitu menjadikan siswa lebih aktif dalam pembelajaran, siswa dapat memahami benar konsep yang telah dipelajari, jawaban yang menimbulkan rasa puas pada siswa.

Negeri 3 Raha. Hal ini didasarkan pada nilai $\frac{1}{2}$ signifikansi uji independent sample $t$ test 0,048 lebih kecil dari $\alpha$ (0.05) yang berarti bahwa terdapat pengaruh yang signifikan model pembelajaran Penemuan Terbimbing terhadap hasil belajar matematika siswa kelas VII SMP Negeri 3 Raha.

Dari hasil penelitian ini dapat disarankan beberapa hal sebagai berikut.

1. Kepada guru kiranya dapat sering melakukan variasi dalam penggunaan model pembelajaran sesuai dengan 
kondisi kelas dan membiasakan siswa sebagai pusat kegiatan pembelajaran.

2. Bagi peneliti yang hendak mengembangkan penelitian ini dapat

DAFTAR PUSTAKA

Arikunto, 2015. Prosedur Penelitian Suatu Pendekatan Praktik. Jakarta: PT. Rineka Cipta.

Fitmawati, Entya Esa. 2016. Efektivitas Model Pembelajaran Discovery Learnig Terhadap Hasil Belajar Siswa Pada Materi Perbandingan Ditinjau Dari Kemampuan Matematika. Skripsi Program Studi Pendidikan Matematika. Kediri. Universitas Nusantara PGRI.

Jihad, Asep dan Haris, Abdul. 2013. Evaluasi Pembelajaran. Yogyakarta: Multi Presindo.

Lestari, E.K dan Yudhanegara, R. M. 2017. Penelitian Pendidikan Matematika. Bandung: PT Refika Aditama.

Priansa, Donni Juni. 2015. Manajemen Peserta Didik dan Model Pembelajaran. Bandung: Alfabeta.

Sudjana, 2013. Dasar-Dasar Proses Belajar Mengajar. Bandung: Sinar Baru Algensindo.

Sugihartono. 2007. Psikologi Pendidikan. Yogyakarta: UNY Press.

Suhana, dan Cucu. 2014. Konsep Strategi Pembelajaran. Bandung: PT Refika Adiatama.

Sukandi, 2014. Strategi Pembelajaran. Bandung: Rosda Karya.

Syah, M. 2004. Psikologi Pendidikan Suatu Pendekatan Baru. Bandung: PT. Remaja Rosdakarya. melakukannya pada pokok bahasan lain yang cocok seperti kubus dan balok. 